\title{
Multiculturalidad y arte en Valencia en la Edad Moderna. Fuentes para su estudio ${ }^{1}$
}

\author{
Borja Franco LLOPIS \\ Universitat de Valencia. Departament d'Història de l'Art. Profesor Ayudante Doctor.
}

\section{RESUMEN}

En este texto analizaremos las fuentes para el estudio de la religiosidad y el arte en Valencia durante el siglo XVI atendiendo no sólo a el catolicismo imperante sino también al protestantismo y al colectivo morisco que coexistieron en dicho territorio condicionando las manifestaciones que allí tuvieron lugar.

Palabras clave: Pintura; Valencia; moriscos; Reforma Católica; Inquisición, tratadística.

\section{Multiculturality and art in Valencia in the Modern Age. Sources for its study}

\begin{abstract}
This paper talks about the sources for the study of the religiosity and Art in Valencia during 16th Century, attending not only to Catholic ideology but also to Protestant theology and moriscos ideas, which coexisted with in this territory determining its Art.
\end{abstract}

Keywords: Painting; Valencia; Moriscos; Catholic Reform; Inquisition; art sources.

El estudio del arte que se desarrolló en Valencia durante el siglo XVI e inicios del XVII conlleva implícito una serie de variables socioculturales que le dieron un valor más allá de los propios valores intrínsecos estilísticos o de forma. No cabe duda que el territorio levantino fue uno de los primeros, dentro de la Península Ibérica, que tomó parte del incipiente italianismo renacentista que se iba imponiendo en Europa. La llegada de pintores como Paolo da San Leocadio o Francesco Pagano, además de los viajes a la Península Itálica de otros artistas que desarrollaron su labor en la sede episcopal, como los Hernandos, autores de las puertas del retablo de la Catedral, supusieron la introducción de un lenguaje que fue ganando fuerza

1 Este trabajo se ha realizado dentro del Proyecto de Investigación I+D+I HAR2009-07740 del Ministerio de Educación y Ciencia, Plan Nacional 2009-2012: La configuración de la Pintura Mediterránea del primer Renacimiento en la Corona de Aragón (c. 1435-1540). Problemas de pintura. Científico director: Dr. Ximo Company. 
y muestra su máximo esplendor de las manos de Joan de Joanes, para muchos, el mejor pintor del Renacimiento hispánico.

Dichas particularidades a las que nos referíamos al inicio del texto vienen dadas por la coexistencia de diversas facciones religiosas conviviendo bajo la atenta mirada del poder político y eclesiástico, acérrimo defensor de la ortodoxia de la fe. Se produjeron tímidas incursiones de ideología protestante, corrientes iluministas y destaca, sobre todo, la minoría (o no tan minoría, ya que era más de un tercio de la población) de origen morisco, que habían sufrido las conversiones forzosas a inicios de la década de los años 20, coincidiendo con la Batalla de las Germanías y que se veían obligados a vivir en un criptoislam, ocultos, perviviendo su cultura mientras que de puertas a fuera, tenían que demostrar ser buenos cristianos para no caer bajo el acoso de la Inquisición.

En estas páginas trataremos de mostrar, de modo abreviado, las principales fuentes para estudiar la función del arte, los fenómenos de recepción así como las teorías de representación que se desarrollaron impulsadas por la moda y las necesidades de adoctrinamiento y defensa de la religión, con el fin de construir una herramienta para futuras investigaciones que versen sobre dichos aspectos.

\section{Los Concilios provinciales}

A través de esta fuente podemos comprobar cómo se aplicaron las recomendaciones tridentinas en cada diócesis, con sus particularidades. Habitualmente, en lo relativo a las imágenes, se suelen detener poco en explicar los aspectos tratados en la última sesión del Concilio, más bien repiten los mismos argumentos aludiendo a lo expuesto en el Tridentino. En el caso valenciano, el primero en realizarse data de 1565, aplazado durante un tiempo debido a la indisposición del por entonces arzobispo Martín Pérez de Ayala.

Dos aspectos referidos a las imágenes, y sin ser decreto dedicado exclusivamente a ellas, se nos presentan en este concilio como novedad ante Trento. Si allí el tema de las reliquias era estudiado conjuntamente con el de las representaciones artísticas, en el caso valenciano tiene todo un apartado dedicado sólo a ellas a través del cual podemos conocer algunos aspectos de la religiosidad popular habituales en la archidiócesis, como sería el de medir las imágenes de los santos con hilos para llevarlos a los enfermos y otras prácticas supersticiosas ${ }^{2}$.

2 "Que no se abuse de las reliquias para sacar dinero. Como que algunos para sacar dinero abusan con mucho escándalo de las reliquias de los santos, á las que con razon debemos honrar y venerar [...] manda [...] que en los templos, aunque sean de monasterios, no se saquen las reliquias de los santos fuera del altar, y que se coloquen en sitio donde el pueblo eche limosnas. [...] y como que debe prohibirse cuanto huela á superstición, ordena, que nadie mida las imágenes de los santos con hilos ó cualquiera otra cosa, para llevar las medidas á los enfermos, ni se den á estos las hostias en que suelen escribirse algunas cosas". "El Concilio Provincial de Valencia de 1565", en Colección de cánones de todos los concilios de la Iglesia de España y de América, recopilados por Juan Tejada y Ramiro, t. V, Madrid, Imp. de A. Santa Coloma, 1861, p. 300. 
El segundo de ellos, se refiere a las imágenes de las cofradías. Estas agrupaciones de feligreses solían tener en sus casas o locales representaciones artísticas a las que rendían culto, pero no siempre lo hacían de modo canónico, cayendo en peligro de idolatría; ni las tenían en lugares decentes y bien cuidadas, por lo que el Concilio, para evitar cualquier problema en su veneración decidió dedicar un decreto a éstas para su control ${ }^{3}$.

Pero para nuestro interés, fue la disposición IX de la quinta sesión la que mayor interés nos presenta. El texto de la misma reza lo siguiente:

"Que se pinten y esculpan con decencia las imágenes de los santos: Conviene que las imágenes de los santos, que con razon se colocan en las iglesias para culto de ellos y enseñanza del pueblo, estén tan decentes y honestas, que ni puedan servir de ofensa, ni degenere en mal lo que se instituyó con buen fin. Por lo cual, y siguiendo las huellas del concilio Tridentino, manda el sínodo, bajo pena de escomunión, que ninguno pinte imágenes de santos con belleza provocativa, ni con trages lascivos y deshonestos, sino de manera que nos manifiesten la santidad de aquellos á quienes representan. Y si hubiere algunas imágenes pintadas indecorosamente, ó esculturas deshonestas, y en especial en los templos, manda severamente á los párrocos y á sus vicarios, que cuanto antes las quiten."

Encontramos gran cantidad de ideas importantes para el análisis de la pintura española de los siglos XVI y XVII. En primer lugar, ratifica el valor didáctico del arte como enseñanza del pueblo, por lo que la rectitud y decencia de las obras debe de ser manifiesta para la transmisión de dogmas verdaderos; de ahí que se critiquen las imágenes lascivas o de belleza provocativa que pueden inducir más al pecado que a la oración. Es decir, se busca el decoro. Este concepto, que nace con el significado de "adecuación al fin", pronto irá tomando connotaciones diversas a medida que vaya siendo apropiado por las élites religiosas. Como señala Martínez Burgos, va sufriendo una evolución de la que nace reinventado ${ }^{5}$ Teoría compartida por Gutiérrez de Ceballos ${ }^{6}$. De ahí se desprende cómo la inclusión de este vocablo en el texto valenciano no es baladí, responde a una necesidad concreta de la Iglesia, una defensa de sus dogmas frente ataques y la búsqueda de la ortodoxia en el arte.

3 "De las imágenes de las cofradías. Como que algunos parece que hacen uso de sus casas privadas como si fueran templos sagrados, y esto no sea conveniente, manda el sínodo, que las imágenes de las cofradías de que suelen usar los hermanos en sus solemnidades y funerales, no se conserven en las casas particulares, como no se dentro de urnas, y en un sitio honesto y decente. Y cuando hubiere que llevarlas á funerales, ó para otras cosas, condúzcanse dentro de las mismas urnas y con decencia; pero sin pompa." Ibid., p. 308.

4 Ibid., p. 308.

5 MARTÍNEZ-BURGOS GARCÍA, Palma, "El decoro. La invención de un concepto y su proyección artística”, en Espacio, Tiempo y Forma, n 2, 1998, pp. 91-102.

6 GUTIÉRREZ DE CEBALLOS, Alfonso Rodríguez, "Iconografía y Contrarreforma: a propósito de algunas pinturas de Zurbarán", en Cuadernos de arte e iconografia, nº 4, 1989, pp. 97-115. 


\section{Los Sínodos Diocesanos}

Es una de las fuentes más indicada para conocer el magisterio de cada prelado, ver qué ideología desarrolló, con qué severidad aplicó Trento, si se avanzó a él, si prestaba atención al tema de las imágenes, etc. Entre 1548 y 1600 se celebraron en la diócesis valentina 15 sínodos. El primero fue el de Santo Tomás de Villanueva, comenzado en junio de $1548^{7}$. Rompió la tendencia de descuido y absentismo episcopal al que había estado sometida la diócesis. Partió de su propia experiencia, así como de las visitas realizadas para conocer el estado diocesano y proponer maneras de mejorarlo. No encontramos en él referencias al campo artístico, aunque sí a la evangelización necesaria de los jóvenes, de cualquier facción religiosa, con el fin de cristianizarlos.

Posterior al de Villanueva fue el que realizara Martín Pérez de Ayala al poco tiempo de finalizar el Concilio Provincial ${ }^{8}$. Celebrado en 1566, el texto sinodal es en sí un reflejo de su personalidad, cómo se preocupa por cada uno de los aspectos que más carencia presentaba en la diócesis, fuera la formación del clero, la autoridad episcopal o el tema morisco, no debiendo entender dicho sínodo como una repetición del concilio que le antecedió. El tema de las imágenes y del adoctrinamiento morisco no tiene gran relevancia en esta fuente, o al menos, no tanta como en el Concilio que ya estudiamos.

Estas mismas preocupaciones fueron compartidas por su sucesor, el Patriarca Ribera. Fue el que más sínodos realizó durante su mandato, un total de 7 con temáticas muy diversas, dependiendo de lo que urgía en cada momento, demostrando gran versatilidad en su gobierno.

El primero fue celebrado en $1578^{9}$, el segundo en 1584 , el tercero en $1590^{10}$, en el mismo año que realizaría también el cuarto ${ }^{11}$. El quinto se celebró en $1594^{12}$, del sexto no conocemos la fecha exacta, ya que ninguna de las fuentes consultadas lo anota, pero sería en los últimos años de la década de 1590, y el último del año $1600^{13}$.

7 La edición consultada ha sido la de PÉREZ DE HEREDIA Y VALLE, Ignacio, Sínodos medievales de Valencia, Roma, Publicaciones del Instituto español de Historia eclesiástica, 1994, pp. 370-387.

8 La edición consultada se encuentra en SAINZ DE AGUIRRE, José, Collectio maxima conciliorum omnium Hispaniae..., t. V, Roma, Ec typographia Anthony Fulgonii apud sanectum Eustachiom, 1753.

9 Synodus diocesana Valentiae celebrata, praeside Illustrissimo ac reverendissimo D. D. Ioanne ribera Patriarcha Antiocheno et Archiepiscopo Valentino, Anno 1578, Valencia, apud Alvarum Francum et Gabrielem Ribas, 1594.

${ }^{10}$ SAINZ DE AGUIRRE, José (1753), op. cit.

11 Ibid.

12 Ibid.

${ }_{13}$ Este último no se conserva íntegro, debido a los incendios ocurridos en la Catedral y Archivo Diocesano, pero Benlloch Poveda afirma que podría reconstruirlo partiendo de diversos manuscritos catedralicios y de Escolano. A día de hoy no hemos encontrado la edición del mismo. BENLLOCH POVEDA, Antonio, "Sínodos valentinos y reforma a finales del siglo XVI", en Corrientes espirituales en la Valencia del siglo XVI 
De todos ellos, el quinto será uno de los que más nos interese, ya que vuelve al tema de las imágenes de las cofradías que el Concilio Provincial de 1565 había ya iniciado, insistiendo en la necesidad de la decencia de las mismas y cómo deberían

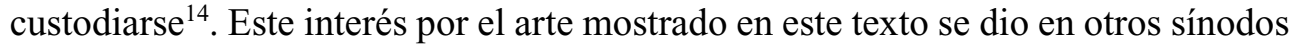
de diócesis afines, como la de Orihuela, en el convocado en 1600, en la primera sesión, capítulo XIV, vuelve a hablarnos de esa belleza lasciva y falta de decoro, mostrando un continuo interés y preocupación por este aspecto.

\section{Las visitas pastorales}

Son una de las fuentes más importantes para conocer el sentir religioso de una diócesis. A través de ellas podemos estudiar cómo afrontó el obispo el análisis de los problema que acechaban a sus feligreses, cómo se comportaba el clero, qué actuaciones debían plantearse para mejorar la situación en la que se encontraba, las principales devociones, en definitiva, el estado social y religioso del territorio. De todas maneras, no sólo podremos constatar de modo documental todos los aspectos citados, sino también realizar una sociología del pueblo, y, a veces aún más importante, del obispo que se encargó de su control. Tanto es así, que investigadores como M. Cárcel Ortí opinan que es la fuente más segura para el estudio de la práctica religiosa local y la mejor documentación para el estudio de las devociones colectivas, partiendo del punto de vista de la propio institución religiosa ${ }^{15}$.

De todas maneras nos encontramos con un problema bastante grave en su estudio. Debido a las contiendas bélicas (sobre todo en el caso de Valencia), gran cantidad de las visitas pastorales que se realizaron se han perdido. M. Cárcel Ortí y Trenchs Odena ${ }^{16}$ se encargaron de realizar un catálogo de la documentación conservada. Una de las fuentes de mayor valor para reconstruir la información que nos dejaron las visitas pastorales valencianas es la obra de Sanchis Sivera, que en su conocido Nomenclator Geográfico-eclesiástico de los pueblos de la Diócesis de Valencia ${ }^{17}$ realizó un recorrido pueblo a pueblo describiendo cada cosa que ve o que

(1550-1600), Actas del II simposio de Teología Histórica, (Valencia, 1982), Valencia, Facultad de Teología San Vicente Ferrer, 1983, pp. 169-182.

${ }^{14}$ En el decreto primero señala: "Todo este Sínodo lleva pesadamente y con impaciencia el que las imágenes de las cofradías insignes por muchos títulos, y hacia las cuales el pueblo es propenso a la devoción, sean tenidas sin embargo en nuestra ciudad menos decencia de la que es debida. [...] Son llevadas a las casas de los artífices de los más inferiores (zapateros) y son colocadas en sus talleres [...] y se ponen en venta mercadurías profanas. [...] y no pocas veces en las alcobas en cuyos lechos se duerme por la noche". SAINZ DE AGUIRRE, José, (1753), op. cit., p. 1594.

${ }^{15}$ CÁRCEL ORTÍ, Milagros, "Hacia un inventario de visitas pastorales en España de los siglos XVIXX", en Memoria Ecclesiae, no 15, 1999, p. 10.

${ }^{16}$ CÁRCEL ORTÍ, Milagros y TRENCHS ODENA, José, “Las visitas pastorales de Cataluña, Valencia y Baleares", en Archiva Ecclesiae, n 22, 1979-1980, pp. 491-500.

17 SANCHIS SIVERA, José, Nomenclator geográfico eclesiástico de los pueblos de la Diócesis de Valencia, Valencia, Tipografía Moderna a cargo de Miguel Gimeno, 1922. 
contaron las visitas antes de su destrucción en la guerra. Por ejemplo, referido al tema morisco, señaló cuántas casas ocupaban en época del Patriarca, qué rectorías se crearon, así como el modo de repoblación, devoción, origen del cristianismo o algunos estudios preliminares y personajes ilustres de la misma. También nos interesa esta fuente ya que aporta referencias a obras artísticas custodiadas en iglesias valencianas, hoy, perdidas, pudiendo suplir, como se anotó, las deficiencias en el material conservado.

En este aspecto fue, de nuevo, el Patriarca Ribera el gran reformador. Sabemos que realizó cientos de visitas pastorales, que la Sagrada Congregación de Ritos encontró transcritas en 91 volúmenes manuscritos relativos al periodo entre 1569 y su muerte (1611). Sólo conservamos una visita, que ha sido motivo de un detallado estudio de $\mathrm{M}$ Cárcel $^{18}$, convirtiéndose su artículo y la visita en sí en el único documento a analizar. Esto dificulta enormemente nuestro propósito de mostrar, a través de esta fuente, la influencia tridentina y el magisterio de Ribera en la zona de Valencia, pero aun así, a través de ella, podemos conocer algunos detalles como que cada año, salía a revisar la diócesis, conociendo todas las necesidades de las iglesias y de los pueblos (no sólo espirituales, sino también físicas, materiales, importándonos para el estudio del arte), predicando y confirmando personalmente en todos ellos.

\section{Los catecismos}

Son una de las fuentes más interesantes para conocer el sentir religioso de la época. Éstos van adquiriendo en la historia una evolución análoga a las predicaciones, unas veces más cercanos a la controversia, otras más moralizantes, siendo un reflejo claro de las necesidades más urgentes de la diócesis. Así pues, las transformaciones del discurso catequético presentan interesantes puntos en común con las formas de evangelización y con el uso del arte en ella.

Desde inicios del siglo XVI se produjo una producción seriada de catecismos en el territorio valenciano. Uno de los primeros fue la Doctrina christiana de Jorge de Austria, reeditada posteriormente por Martín Pérez de Ayala ${ }^{19}$. Lo mismo ocurrió con la Cartilla y breu instructio de la doctrina cristiana ${ }^{20}$, que escrita por Francisco

${ }^{18}$ CÁRCEL ORTÍ, Milagros, "Una visita pastoral del pontificado de San Juan de Ribera en Valencia (1570)", en Estudis, no 8, 1980, pp. 71-85.

19 Les instructions y ordenacions per als novament convertits del regne de Valencia fetes per les autoritats Apostolica y Real, y ordinaria per los Ilustrisimos, y Reverendisimos senyors don Jordi de Austria Archebisbe de Valencia, e don Antonio Ramíres de Haro, Bisbe de Ciudad Rodrigo... Les quals lo Ilustris. y Reverendis. senyor don Martin de Ayala Archebisbe de Valencia, apres de vistes y examinades en el Sínodo...., Estampades en Valencia per Alvaro Franco y Gabriel Ribas, 1594.

${ }_{20}$ Cartilla y breu instructió de la Doctrina Cristiana, ordenada per manament del Illustrissim e Reverendissim senyor Don Francisco de Navarra per la divina gracia Archebisbe que fonch de Valencia. Impressa per manament del Illustrissim e reverendissim senyor don Ioan de Ribera Patriarca de Antiochia, e Archebisbe de Valencia, Estampada en Valencia, 1571. 
de Navarra fue transcrita en 1571 por el Patriarca Ribera, en su intento de conseguir la conversión morisca.

Toda esta recuperación y publicación de obras anteriores vino acompañada de la redacción de otras nuevas, cuyo fermento radica en la misma Edad Media (con autores como Llull a la cabeza), donde el problema musulmán, así como la necesidad de instrucción al pueblo era también una preocupación latente en la sociedad. Estas obras modernas con regusto medieval podrían estar encabezadas por el Antialcorano (escrito en 1528 pero publicado en 1532) y los Diálogos christianos (1535), obras del canónigo de la Colegiata de Gandía, Bernardo Pérez de Chinchón. En los 26 sermones que comprendía su Antialcorano pretendía suministrar material doctrinal a todos los rectores y a las personas eclesiásticas que se encargaban de la conversión y de la evangelización morisca; a la vez que apelar al Arzobispo Erard de la Marck (ocupó el cargo entre 1520 y 1538) de la necesidad de una participación activa en la resolución de dicha tensión.

Éste sirvió como fermento para obras posteriores como la de Martín Pérez de Ayala, quien nos legó la Doctrina Christiana en lengua Aráviga y Castellana, publicada en 1566. Esta obra presenta bastantes peculiaridades. La más significativa es que el texto castellano viene acompañado por una traducción interlinear en árabe pero con caracteres latinos, con el fin de proporcionar a los catequistas un manual (incluso fonético) con el que desarrollar su labor, entroncando con la ideología lullista, del conocimiento del árabe en el acercamiento a las minorías.

El Patriarca Ribera recogió el testigo y publicó otro catecismo en 1599, basado en el de Ayala, por mandato de Felipe III. El objetivo sería el de demostrar la superioridad del cristianismo sobre la religión musulmana, y, a su vez, la búsqueda de una catequesis sistemática antes del bautismo para una conversión sincera.

Desgraciadamente, estos catecismos estudiados, frente a la gran mayoría de los producidos en la época, presentaban un número reducido de imágenes, salvo en la portada y contraportada, teniendo mayor valor en el estudio sociológico de la población que en el uso del arte en sí. De todas maneras conservamos documentación del envío de catecismos por parte San Francisco de Borja, general de la orden jesuítica en dicho periodo, que nacieron de las imprentas en el mismo Colegio Romano, los cuales incluían imágenes e incluso notas en caracteres árabes. De todas maneras, la pérdida de bastantes inventarios de bibliotecas por la desamortización o quema de documentos, nos imposibilita, a día de hoy, realizar un estudio en profundidad de la recepción de los mismos al ser ínfimo el número encontrado en nuestro territorio.

\section{Sermonarios y teatro litúrgico}

Se han unido estas dos fuentes: sermonarios y obras dramáticas como ejemplo de literatura oral que, posteriormente, se plasmó en papel (no en todos los casos), 
siendo capital para conocer el sentir popular de dicho momento. Ya los definía Gutiérrez de Ceballos como los mass media y difusores de ideas más importantes de la Edad Moderna ${ }^{21}$ por inducir al público a la devoción y plegaria. El predicador se convertía en un showman que debía captar la atención de los feligreses, para ello, no ahorraba gestos, modulaba la voz, y, aún más importante para nosotros, utilizaba el arte como medio de persuasión y complemento de sus parlamentos.

Así pues, debemos hablar del uso del arte en un doble sentido, el primero el de conseguir mayor efectividad persuasiva en el auditorio, pudiéndose producir cierta asociación entre pintor y predicador, por cuanto el segundo solicitaba al artista alguna imagen pintada o esculpida para ayudar en su tarea (tal podría ser el caso entre Juan Bautista Agnesio y Joan de Joanes, que mantuvieron una estrecha relación de amistad) o, en segundo lugar, el uso de la imagen en la reproducción escrita de dichos sermones, como complemento al texto y ayuda para la oración mental.

Uno de los predicadores que mayor éxito y halo de santidad obtuvo en la Edad Moderna valenciana fue San Luis Bertrán. El estudio de sus prédicas ha permitido conocer cuáles eran sus mayores temores, y con ello, las preocupaciones del clero finisecular. Si bien conservamos una ínfima parte del conjunto y en algunos casos nada más que alguna somera anotación marginal; no nos impide valorar como dos fueron sus preocupaciones: los herejes luteranos y el gran problema morisco. Todo ello acompañado de constantes referencias a la validez de los sacramentos y de los ritos y a la crítica a la perdición del clero. Él mismo se encargó de fomentar la reproducción seriada de cruces de madera que utilizaba en sus prédicas para convencer al auditorio y luchar contra los brotes iconoclastas que las destrozaron en territorio hispánico.

Del Patriarca Ribera sí que conservamos la mayor parte de sus sermones, gracias al trabajo que realizara Robres Lluch recopilando toda su obra ${ }^{22}$. En sus dos volúmenes podemos conocer las prédicas del santo, la incidencia en la importancia de la Eucaristía, el problema morisco o el temor luterano. De todos ellos, el más destacado por su contenido doctrinal fue el realizado tras la polémica expulsión de los moriscos en $1609^{23}$ en la que presenta como un honor y privilegio lo sucedido, porque gracias a ello fue Valencia el primer territorio en verse libre de esta herejía y tuvo la oportunidad de demostrar su fidelidad al catolicismo y a la monarquía.

En la misma dirección que los sermones, y con una representación más dramática y escenificada nos encontramos las obras teatrales. Es imposible, en este

${ }^{21}$ GUTIÉRREZ DE CEBALLOS, Alfonso Rodríguez, "La literatura ascética y la retórica cristiana en el arte de la Edad Moderna: el tema de la soledad de la Virgen en la plástica española", en Ephialte, n 2, 1990, p. 81 .

22 SAN JUAN DE RIBERA, Sermones de los tiempos litúrgicos, Edición crítica y trascripción realizada por el canónigo Ramón Robres Lluch, Valencia, Corpus Christi, 1987.

${ }^{23}$ Para mayor información al respecto vid SEGUÍ CANTOS, José, "La razón de estado: Patriarca Ribera y moriscos (1599-1609-1999)", en Estudis. Revista de Historia Moderna, no 25, 1999, p. 108 y ss. 
artículo citar todas las representaciones teatrales escritas en los siglos XVI y XVII en Valencia, por ello nos centraremos en dos. Una de las más importantes y menos estudiadas ha sido la obra Ad illustriss [imum] Príncipem Dominum Goergium ab Austria reverendissimum Valentinatum Archimystem.... Pro Saracenis Neophytis... publicada dentro del volumen de las Apologías en 1543 y escrita por Juan Bautista Agnesio. Tal vez esta obra nunca fuera representada, ya que si el objetivo principal era el de utilizarla para la evangelización morisca, estaba escrita en un idioma no conocido por ellos (latín) por lo que difícilmente podría conseguir su fin. Con ello se le atribuye a la composición agnesiana un carácter más poético que dramático. Debemos verla como una obra a favor de la asimilación de este colectivo en la que él confiaba claramente y que conocía de primera mano. En sus 87 dísticos hizo una apología a su conversión y a continuar con los métodos pacíficos de adoctrinamiento. Agnesio fue predicador en tierra de moriscos y contó con la presumible ayuda de Joan de Joanes en la creación de una iconografía útil para la conversión.

Si el texto de Agnesio resumió la preocupación por el problema morisco, Joan de Timoneda en su Església militant (1575) se encargó de mostrarnos el temor hacia los protestantes, unido con ciertas citas a la temida invasión turca. Este auto sacramental narra la lucha de los ejércitos cristianos ante la herejía. Las armas para dicho combate son la fe y la confianza en la Eucaristía. Nos presenta un diálogo principalmente entre dos personajes: la Iglesia y Cristo, que son los encargados de mostrarnos las penurias y problemas políticos, religiosos y culturales valencianos finiseculares. Gracias a ella hemos podido constatar ese sentimiento de los valencianos ante los temores de ocupación, ya fuera ideológica o física, de sus enemigos, su inestabilidad política y religiosa o la confianza en el monarca y pontífices para conseguir la paz.

\section{Los tratados de arte}

Sería impensable realizar un estudio de la pintura valenciana de los siglos XVI y XVII sin utilizar una de las fuentes que más información nos dan sobre las normas o tendencias artísticas que se desarrollan en este momento. Uno de los primeros escritos en nuestro territorio sería el de Martín Pérez de Ayala, arzobispo de Valencia (en aquel entonces, aún obispo de Guadix), titulado De divinis apostolicis atqve ecclesiasticis traditionibus... ${ }^{24}$ de 1563 . Partiendo de las teorías aristotélicas, de un conocimiento profundo del protestantismo y sus ataques a los católicos, supo escribir este tratado donde rechaza la idolatría tergiversando, en cierto modo, algunos decretos del Concilio de Elvira. Defiende la veneración de las reliquias de los santos, de sus sepulcros y de las imágenes. Partió de la base de que las imágenes

24 PÉREZ DE AYALA, Martín, De divinis apostolicis atqve ecclesiasticis traditionibus déque authoritate ac vi earum sacrosancta adsertiones ceu libri decem aucti \& correcti..., París, apud Gulielmum Iulianum..., 1562 . 
apelaban al intelecto y que era un medio fundamental de adoctrinamiento, si se unía a la palabra. De todas maneras, es curioso que Ayala dedicara un texto a este tema. Si lo hizo, creemos que fue, más bien, porque era una necesidad en las diócesis donde realizó su labor, ya que no fue uno de los clérigos que mayor apego tuvo a la causa artística. En su corto periodo en la sede valentina, apenas encargó alguna obra, más bien se dedicó al tema legislativo, la convocatoria del concilio y del Sínodo y las visitas pastorales. Mientras que en el caso de Santo Tomás de Villanueva o el Patriarca Ribera, sí que tenemos constancia de su interés por el mundo de la imagen, en Ayala no. Todo ello no implica que no conociera bien la teoría de las imágenes y que defendiera su utilidad.

Partiendo de este interés por la codificación del campo artístico, podemos entender la aparición en Valencia de uno de los textos más interesantes del periodo. La historiografía tradicional ha marginado uno de los tratados, a nuestro entender, más importantes del momento, posterior en pocos años al de Paleotti, pero muy por delante de los de Pacheco y otros citados anteriormente. Nos referimos a la Historia de la adoración y uso de las Santas Imagenes y de la imagen de la Fuente de la Salud... de Jayme Prades, publicado en Valencia en $1596^{25}$. Su obra, según nos cuenta, fue fruto de los ataques de los herejes alemanes, ingleses y franceses. En ella, siguiendo un tanto el esquema creado por el citado Paleotti, nos define qué es la imagen, cuándo será sagrada, porqué es lícita a pesar de las prohibiciones del Antiguo Testamento, su uso didáctico, la relación con la oratoria, la necesidad del retorno a los textos canónicos, la diferenciación entre "latria", "dulia" e "hiperdulía"; o el cometido del pintor como persuasor o difusor de dogmas.

Pero no debemos quedarnos eclipsados con este magnífico tratado citado, pues conservamos textos dignos de mención. El más importante de ellos, incluso anterior al de Prades, es un opúsculo a la segunda edición de una obra de pedagogía y civismo del humanista Juan Lorenzo Palmireno llamada El Estudioso de la Aldea $(1571)^{26}$, cuyo título es Declaracion de lo que el cristiano vee en los sagrados templos. Esta pequeña obrita fue mencionada por primera vez por Marías en su trabajo sobre el siglo $\mathrm{XVI}^{27}$ a colación de las explicaciones que nos da el autor sobre las tipologías de plantas, los ornamentos, la función de la pintura y de dónde se colocaban éstas (puertas, espaldas de altares, casullas sacerdotales...). Nos interesan las palabras de Palmireno porque es curioso como, al hablar del término de idolatría y del valor didáctico del arte no se refiere a los protestantes, sino a los musulmanes,

${ }^{25}$ La edición utilizada ha sido PRADES, Jaime, Historia de la adoración y uso de las Santas Imagenes y de la imagen de la Fuente de la Salud..., en Valencia en la impresión de Felipe May, 1597. Véase al respecto el estudio que realizamos en la revista Ars Longa, $\mathrm{n}^{\circ}$ 19, titulado "Redescubriendo a Jaime Prades, el gran tratadista olvidado de la Reforma Católica", 2010, pp. 83-93.

26 La edición utilizada ha sido: PALMIRENO, Lorenzo, El estudioso de la aldea. Añadiose en esta segunda impresion el borrador y la declaracion de lo que el cristiano vee en los sagrados templos, Valencia, Impresso en casa de Pedro de Huete, 1571.

27 MARÍAS, Fernando, El siglo XVI. Gótico y Renacimiento, Madrid, Sílex, 1992, p. 186. 
lo que nos da a entender que, para los valencianos de la época, el problema de la iconoclastia y la mayor inestabilidad social por las críticas artísticas no provenía de la amenaza luterana sino de algo que tenían mucho más cerca; nos referimos pues, a los moriscos. Este texto justifica esta visión multicultural del arte valenciano, no focalizando nuestro interés sólo en las recomendaciones trentinas sino también en los problemas internos de la región.

\section{Libros de historia coetáneos}

Para una reconstrucción fidedigna de la sociedad moderna, una de las fuentes que debemos consultar son aquellos textos históricos escritos en el mismo periodo que analizamos, es decir, crónicas o anales que intelectuales valencianos escribieron para recordar el pasado glorioso del territorio y las bondades del tiempo en que vivieron.

Una de las primeras crónicas de estas fechas fue la de Pedro Antonio Beuter, publicada en dos partes ${ }^{28}$. Su obra obtuvo una enorme difusión, como lo demuestra el hecho de que se editara en Venecia apenas diez años después de que la primera parte española viera la luz. Beuter ofrece valiosos testimonios, como la que se considera la cita más antigua sobre yacimientos arqueológicos españoles así como una narración bastante documentada de la historia tanto de Valencia como de toda la Península.

Siguiendo su estela podemos entender una de las obras magnas de la Edad Moderna valenciana que ha sido y sigue siendo referencia en todo análisis histórico de nuestro pasado por la información que nos concede. Hablamos de las Décadas de la Insigne y Coronada Ciudad y Reino de Valencia (1610) de Gaspar Escolano. Teólogo, historiador y cronista, es toda una institución dentro del campo de la historiografía valenciana. Su publicación contiene una relación de los hechos históricos acontecidos hasta el reinado de Pedro El Grande de Aragón, incluyendo la rebelión de los moriscos y su expulsión. Nos ofrece abundante información sobre la economía del Reino de Valencia, sus instituciones, su geografía, sobre los linajes valencianos, etc. Esta gran obra podríamos completarla con el texto Martín Viciana, titulado Chronyca de la inclita y coronada ciudad de Valencia y de su reyno (1564), de menor calidad literaria pero útil por su enfoque histórico.

De mayor utilidad por su viveza y gran cantidad de detalles que nos ofrece sería el dietario de P. J. Porcar ${ }^{29}$. Se trata de la narración, por parte de un sacerdote

${ }^{28}$ BEUTER, Pedro Antonio, Primera part d'la Historia de Valecia que tracta deles antiquitats de Spanya y fundacio de Valecia, ab tot lo discurs fins al temps q lo inclit rey do Jaume Primer la coquista, [s.n.], Estampat a Valencia, 1538. Y, de la segunda: Segunda parte de la Coronica general de España, y especialmente de Aragon, Cataluña y Valencia..., Valencia, casa de Ioan de Mey, 1551.

29 PORCAR, Pere Joan, Coses evengudes en la ciutat e regne de Valencia (1589-1628), Dietari, edición transcrita y con prólogo de Ferran Garcia Garcia, Valencia, Diputació Provincial de València y la Institució Alfons el Magnànim, 1983. 
beneficiado de la Iglesia de San Martín de Valencia de la historia de la ciudad y lo que le rodea: costumbres, acontecimientos de la vida cotidiana, etc. Éste participa de la reacción contrarreformista al servicio de un programa político que exalta la unidad del catolicismo y la necesidad de unas instituciones defensoras del ideal católico contra los luteranos, calvinistas, moros o sodomitas. Se podría incluir dentro de aquellas memorias colectivas como muestra de una resistencia pasiva ante la decadencia cultural, recordando un pasado que se le presentaba más glorioso y libre. Podemos conocer gracias a ella, por tanto, el día a día visto por un eclesiástico "cualquiera", donde nos presenta noticias interesantes no sólo desde el punto de vista histórico sino también artístico sobre obras en diversas fundaciones de la ciudad.

En esta misma línea podemos enmarcar el Libre de memories de diversos sucesos e fets memorables e de coses senyalades de la ciutat e Regne de Valencia (1308$1644)^{30}$. Se trata de un compendio de sucesos y textos escritos por los diversos clérigos de la Catedral (en algunos casos anónimos), que recopilados por Carreres Zacarés son otro ejemplo del mismo estilo anecdótico de Porcar. Nos muestra aspectos interesantes para la investigación como por ejemplo el robo por parte de los moriscos de la hostia consagrada que impidió la procesión del Corpus en una población de la sierra de Espadán o como fueron detenidos diversos moriscos por quemar iglesias, siendo interesante, por tanto, para el estudio de la iconoclastia de este colectivo.

\section{Tratados sobre la expulsión morisca}

Tras la decisión de expulsar a los moriscos comenzó a generarse una literatura que justificaba esta acción y mostraba todos los horrores perpetrados por esta secta en territorio valenciano. El interés de esta fuente para nuestro estudio radica en conocer cuál era la visión del "otro" en aquellos más acérrimos detractores de la minoría, y, a su vez, estudiar qué sucesos se produjeron como respuesta a la pragmática, siendo, por ejemplo, un caso habitual el de la destrucción de imágenes por parte de los nuevamente convertidos, siendo, por tanto, un hecho de gran interés para nuestro estudio.

Dentro de este epígrafe podríamos incluir la magna obra de Bleda la Difensio Fidei in causa neophytorum. Tractatus de iusta Morischorum ab Hispania expulsione (1610) y la Coronica de los moros de España (1618). También los escritos de Marcos de Guadalajara y Xavier titulados Prodición y destierro de los moriscos (1614) y Memorable expulsión y Vistísimo destierro de los moriscos de España

30 La edición utilizada ha sido CARRERES ZACARÉS, Salvador, Libre de memories de diversos sucesos e fets memorables e de coses senyalades de la ciutat e Regne de Valencia (1308-1644), Valencia, Acción Bibliográfica Valenciana, 1935. 
(1613). La Iusta expulsión de los moriscos de España: con la instrucción, apostasía y Trayción de ellos. Y respuestas a las dudas que se ofrecieron acerca desta materia de Damián Fonseca (1612); o la Expulsion iustificada de los moriscos españoles y suma de las excellencias christianas de nuestro rey Don Felipe el Catholico Tercero: dividida en dos partes (1612) de Pedro Aznar de Cardona, serían otras fuentes de suma utilidad, por no olvidar los textos de Corral y Rojas, Pérez de Culla o Mármol y Carvajal.

\section{Inventarios de bibliotecas y post mortem}

Una de las mejores maneras para conocer la cultura material e inmaterial de la Edad Moderna es el análisis de las bibliotecas, ya fueran de artistas o mecenas; así como sus inventarios post mortem. Gracias a ellos se reconstruye perfectamente qué se leía o, al menos, qué volúmenes poseían. Como ocurre con el resto de fuentes, éstas no iban a ser una excepción, han sufrido bastante con el paso de los años. El deterioro o pérdida por las distintas contiendas bélicas o dejadez patrimonial ha producido que conservemos menor número del deseado de dicha documentación. Aún así, partiendo de los pocos datos podemos sacar algunas conclusiones.

En nuestro territorio destacaron dos bibliotecas o librerías: la de Juan de Borja y la del Patriarca Ribera. El primero de ellos fue el tercer Duque de Gandía ${ }^{31}$. Creció bajo la educación de su madre, María Enriquez, una de las personalidades más influyentes en el mundo espiritual de Gandia; mujer preocupada por el arte, de hecho fue quien contrató de modo exclusivo los servicios de Paolo da San Leocadio tras finalizar sus trabajos en el presbiterio de la Catedral de Valencia. Fueron ambos, madre e hijo, personalidades fundamentales en la educación de San Francisco de Borja, ya que creció rodeado de un sentir religioso concreto que podemos analizar gracias a los ejemplares conservados en esta biblioteca. Entre sus ejemplares encontramos textos de Luca Pacioli o de Leon Battista Alberti.

Nada que envidiar tuvo la colección bibliográfica del Patriarca Ribera ${ }^{32}$. El santo patriarca poseía, al igual que Borja, tanto obras clásicas de la espiritualidad como la Vita Christi del Cartoixà, u obras de piedad mística flamenca como las de Kempis, Mombaer o Ruysbroek. Nos interesa el estudio de su librería ya que contenía obras jesuíticas,

31 PASTOR ZAPATA, José Luis, "La biblioteca de don Juan de Borja. Tercer duque de Gandia", en Archivum Historicum Societatis Iesu, fascículo 122, 1992, pp. 275-308.

32 Estudiada en CÁRCEL ORTÍ, Vicente, “Obras impresas del siglo XVI en la biblioteca de San Juan de Ribera", en Anales del Seminario de Valencia, no 11, 1966, pp. 111-183. Id., "El inventario de la biblioteca de San Juan de Ribera", en Analecta Sacra Tarraconense, n 39, 1968. NAVARRO SORNÍ, Miquel, "Catálogo de incunables y de obras impresas del siglo XVI, no registradas en el inventario de 1966, de la Biblioteca de San Juan de Ribera", en Homenaje a D. Ignacio Valls, Valencia, Facultad de Teología San Vicente Ferrer, 1990, pp. 14- 43. Del mismo autor "La Biblioteca de Sant Joan de Ribera. Espill d'un humanista, exponent de la Reforma Catòlica”, en Domus Speciosa, cat. exp., (Valencia, 2006), Valencia, Universitat de València, 2006, pp. 219-244. 
como las Evangelicae Historiae Imagines, publicada en Amberes por primera vez en 1593, junto con las Adnotaciones et Meditaciones in Evangelia, obras fundamentales para entender la ideología jesuita no sólo de modo escrito sino también visual, al ir ilustrada con grabados realizados por los hermanos Wiericx, consiguiendo la difusión de unos modelos que fueron de amplio interés en aquella época, tanto es así que sería una de las fuentes principales utilizadas por Pacheco para su Arte de la Pintura. Así pues, comprobamos la importancia que tuvo el arte en la oración de Ribera.

Por lo que respecta a los inventarios post mortem de artistas y mecenas, conservamos menor número. Gómez Ferrer nos presenta uno de los estudios más interesantes al respecto, basándose en el testamento del pintor redactado en 1578. Dicha investigadora se centró en la figura de Miguel Urenya, un pintor de segunda fila valencia$\mathrm{na}^{33}$. Es curioso como, a pesar de tener constancia de que pocos artistas valencianos del XVI sabían leer o escribir (salvo raras excepciones como Joan de Joanes, podemos afirmar que la cultura era bastante baja; figuras de nivel como Gaspar Requena o Miguel Porcar carecían de dichos conocimientos) en el caso de Urenya conserva siete volúmenes de obras, algunas de ellas, poco conocidas en Valencia: un Virgilio y un César en latín, el Nuevo Testamento, las fábulas ilustradas de Esopo y tres tratados de arquitectura: el Serlio, una versión del Vignola y un libro de perspectiva de Daniele Barbaro; estas últimas, a buen seguro utilizadas para buscar una corrección en los fondos paisajísticos y con edificios. El testamento de Urenya nos ha posibilitado conocer algunos modelos u obras de arte que poseía, que pudieron servirle de inspiración. Encontramos "modelos de algeps de poch valor. Item un rastre de Nostra Senyora ab son bastiment daurat sense acabar. Item un Ecce Homo en papel pintat al oli. Item un quadre en paper guarnit de fusta de una peça. Item un Sant Francesc en paper guarnit de fusta..."34. Esta información se puede completar con otro inventario trabajado por Hernández Guardiola sobre el pintor Nicolás Borrás, que legó a su sobrino, Francisco Doménech, también del gremio, utensilios para desarrollar el arte de la plástica: "Tots los arreus pera pintar, zo es pincello, colors, pedres de moldre y de bionlor (asi dice), é les dos olles de coure, é ferramentes, é taulono, papers de má, é de estampa, y altres teles de pintura, é tot alló que yo tinch de present en lo convent é monestirs apres obte meu, ó no enans, etc" ${ }^{35}$.

Aunque poco abundantes y, en algunos casos, con datos ínfimos, a través de estos testamentos como de los inventarios de bibliotecas, se ha podido reconstruir espiritualidad que envolvió a patrones y pintores, así como algunas de las herramientas más habituales de estos últimos.

${ }^{33}$ GÓMEZ-FERRER LOZANO, Mercedes, "Inventario de bienes del pintor Miguel de Urenya. La biblioteca de un artista en la Valencia del siglos XVI", en Ars Longa, no 5, 1994, pp 125-132.

${ }^{34}$ Ibid., pp. 129-130.

${ }^{35}$ HERNÁNDEZ GUARDIOLA, Lorenzo, Vida y obra del pintor Nicolás Borrás, Alicante, Excelentísima Diputación Provincial de Alicante, 1976, p. 45. 


\section{Los documentos inquisitoriales}

Como bien es sabido, el papel de la Inquisición fue el de mantener la ortodoxia a rajatabla, tratando de evitar cualquier desviación frente a los cánones impuestos por la Iglesia, sobre todo tras el Concilio de Trento. Gracias a estos procesos podemos conocer muchos de los aspectos de la vida privada de los fieles valencianos. Un claro ejemplo sería la costumbre de poseer imágenes en casa que fomentaran la piedad privada y que fueran muestra de la devoción interior. Por ejemplo, en el proceso contra Juana Benita Pallas, una de las cosas que se anota es que: "en los aposentos no se ha hallado imagen de santo ni santa, ni mesa, ni silla, ni cama ni colchón"36 como si fuera esto un dato representativo de no seguir las normas de la Iglesia y que, junto al hecho de que no participara de las ceremonias del Corpus fue suficiente para que sufriera la condena del Santo Oficio. Todo lo contrario sucedió en el caso de Catherina, una esclava cristiana, en el que su acusación se basó en la espiritualidad exacerbada que profesaba, ya que tenía visiones que partían de la imagen del crucificado que adoraba en sus aposentos ${ }^{37}$. Estos dos casos citados denotan el valor que llegó a tener el arte como elemento representativo de la cultura religiosa moderna y muestra de la piedad interior.

Además, gracias a esta fuente conocemos de primera mano los brotes de iconoclastia que se dieron en nuestro territorio por parte de protestantes y moriscos ${ }^{38}$, como repulsa ante las imposiciones del poder religioso y político a rendirles culto como ejemplo de buena conducta católica. Del mismo modo, a través de su estudio podemos encontrar la visión no sólo de este colectivo hacia el arte, sino también las dudas doctrinales de los propios cristianos viejos, que no saben cómo reverenciar a las imágenes sin incurrir en idolatría ${ }^{39}$.

$* * * *$

A través de estas páginas hemos intentado realizar una aproximación muy somera a las fuentes más importantes para conocer los fenómenos de multiculturalidad que nos presenta el territorio valenciano y qué papel jugó el arte en todo proceso, con el fin de aportar una visión no unidireccional sobre la producción artística en dicho periodo ${ }^{40}$.

\footnotetext{
36 Archivo Histórico Nacional, Inquisición, leg. 557, n 16, 1587.

37 "En que en una cruz que tenia en su aposento veya de seys en seys semanas una figura de Cristo grande llagado manos y costado y venia con el una señora Alta vestida de blanco y cabellos largos y el Cristo se ponia en medio de la cruz y se subia en alto asta el techo trez bezes diziendo hay cruz, cruz cruz", Archivo Histórico Nacional, Inquisición, leg. 533, nº 2, 1588.

38 Veáse una primera aproximación a este hecho en FRANCO LLOPIS, Borja, "En defensa de una identidad perdida: los procesos de destrucción de imágenes en la diócesis de Valencia", en Goya, n 335, 2011, pp. 116-125.

39 Sobre este aspecto véase FRANCO LLOPIS, Borja: "Los moriscos y la Inquisición. Cuestiones artísticas", en Manuscrits, n' 28, 2010, pp. 87-101; Id., "Noticias sobre arte y devoción del Quinientos aragonés a través de la documentación inquisitorial”, en Boletín del Museo e Instituto Camón Aznar, n 107, 2011, pp. 77-92. Y, por último, $I d$., "Consideraciones sobre el uso y abuso de la imagen en la Península Ibérica en el siglo XVI a través de los procesos inquisitoriales. Una visión multicultural del arte: moriscos, protestantes y cristianos viejos", en Sharq-Al-Andalus, 2011. (En imprenta)

40 Para un estudio más detallado del conjunto véase nuestra tesis doctoral disponible on line: http://www. tesisenxarxa.net/TESIS_UB/AVAILABLE/TDX-1030109-134228//FBFLL_TESIS.pdf
} 